\title{
The Flipped College English Writing Class Based on Output-driven Hypothesis
}

\author{
Lin Liu
}

\author{
College of Foreign Language Education, China West Normal University, Nanchong, Sichuan, China
}

Keywords: Flipped Class Model, College English Writing Class, Output-Driven Hypothesis, Autonomous Learning, Personalized Learning

\begin{abstract}
Writing is of great importance in college English teaching. However, the limitation of time in learning English makes it impossible to deal with both the teaching and the practicing of writing inside the classroom. This paper tries to apply the flipped class model to deal with this obstacle. With the combination of students' autonomous learning and practicing in online course and teacher's guidance in offline course, the students would not only be able to figure out "how to write" but also "what to write". The difficulties of both language and content of writing would be solved under the flipped class model.
\end{abstract}

\section{Introduction}

The "flipped class model" is commonly referred as "flipped classroom" or "inverted classroom". The origin of flipped classroom can be traced back to Harvard University in the early 1990s when the Professor Erik Mazur utilized text files and problem solutions that allowed students to control the pace and content of their learning (Mazur, 1991). Many scholars have tried to define the flipped classroom ever since, Jonathan Bergmann and Aaron Sams define flipped class as [a flipped class in this: that which is traditionally done in class is now done at home, and that which is traditionally done as homework is now completed in class. But there is more to a flipped classroom than this. The flipped classroom is a means to increase the time for interaction and personalization between students and teachers] (Bergman and Sams, 2012) Even with some variation, most scholars generally agree that the flipped classroom reverses the process of knowledge learning and assimilation. The flipped classroom has become a hot topic in Chinese educational researches since 2011, and the application of flipped classroom model began from the science-related subjects.

With the support of information technology, flipped class model departs from the traditional teaching model. In a flipped classroom, the students acquire the knowledge with the assistance of online resource before the class, and while the class, the teacher's role has transformed form the lecturer of the knowledge to the organizer of the activities. The students internalize knowledge with the help of teacher and peers via class activities, which is a typical "student-oriented" teaching approach.

\section{The necessity of flipped college English writing class}

\subsection{The importance of writing in college English class}

According to The College English Curriculum Requirements distributed by Chinese Ministry of higher Education in 2007, the college English curriculum is aimed at enhance students comprehensive abilities in English, so the reformed Chinese college English test (CET) take listing, speaking, reading, writing as well as translating into consideration. The English skills can be classified into two large categories: the receptive skills---listening and reading as well as the productive skills---speaking, writing and translating. Based on the output-driven hypothesis proposed by Wen Qiufang, on the one hand, for any foreign language learner who has foreign language foundation and receives formal language education, such as a university student who has been learning English for at least six years, the output needs may motivate him more than the input needs in 
his foreign language learning. The output-driven not only facilitates the application of input knowledge but also inspire the learner to learn more about the language. On the other hand, for the aim of education, cultivating the productive skills like speaking, writing and translating meets the social needs (Wen, 2013).

The ultimate purpose of language learning is to output information. The Chinese students, as EFL (English as a foreign language) learners, seldom have opportunity to practice productive skills in real life. However, in traditional Chinese English classes, the teaching is exam-oriented. The focus of class is to help language learners to input the knowledge while the language learners are busy with taking note and they do not have much chance to output language in the classroom. Writing, as one of the productive skills, takes up a large portion of all kinds of English tests and is of vital importance to the learners' motivation in English learning and needs for future career. So the college English class should attach importance to foster students' writing skill.

\subsection{The obstacles in present college English writing class}

In order to improve the learners' writing skill, besides learning about the theories of writing, the learners need to know how to apply those theories in complicated real language environment. Although writing is a productive task, it is based on receptive learning. The problems students encounter in English writing are not only "how to write", for some English learners, they also face the obstacle about "what to write". Writing is a personalized process, and one's personal experience has much to do with this process. The limitations on Chinese students' English writing are both language proficiency and world knowledge. For example, the writing of College English Test Band 6 in December, 2015 is "the impact of social networking website on reading" and it is a writing task based on a cartoon. In the cartoon, characters have a discussion about reading that "I love reading. I read about 3 hours a day. My favorite book is Facebook". Although the task gave a definition about Facebook: "Facebook is the name of a social net working website", as Facebook is not available in China, many students couldn't interpret the ironic implication in the cartoon which results in the failure in their task achievement.

Meanwhile, there are several obstacles in college English writing class setting. Firstly, in Chinese higher educational institutions, it is a common phenomenon that college English curriculum is set under 300 classes. With the guidance of The College English Curriculum Requirements, the college English teachers have to work to enhance students' comprehensive English skills. As a time-consuming skill, the time allocated to writing class is far from enough, no to mention a successful writing class involves more than just the output of the writing task. Secondly, the time limitation on both College English Test Band 4 and Band 6 is 30 minutes. For a common class in universities and colleges, there is only 40 minutes, so it is not likely to proceed to the whole writing process in a class. Also, the college English is a compulsory course in all China's higher educational institutions, the class scale is often a medium size or even a large size, so it is rather difficult for college English teachers to give detailed feedback on each student's writing instantly. The flipped class model could solve the shortage of classroom time. Before the class, the teacher prepares learning material for students and assigns the students to finish the learning of task-related background information and accumulate vocabulary. While the class, the teacher designs activities to guide students to work on the outline of the writing with the supportive content. After the class, the students finish the writing task on the online writing platform "Pigai".

\section{The practice of flipped college English writing class}

In order to participate in the whole process of knowledge input and writing task output, the students' learning is divided into two parts: online course and offline course. The online course includes students' learning of task-related background information and vocabulary as well as the output of the complete writing task. The teaching goal of an English writing class is not just to enable the students to fabricate error-free sentences, more importantly, is to enable them to express their idea and thought freely. So the flipped college English writing class is an integration of language and content. The before-class online learning and the after-class online writing platform would aid 
students to overcome the language problems. The offline course happens in the classroom where the teacher designs kinds of activities to guide students to form clear thoughts of the writing. With the guidance of teacher and the collaboration of peers, the students would solve the difficulties in the content of the writing. The specific teaching process is designed as follows.

\subsection{The input of task-related knowledge before class}

Under the flipped class model, the teacher prepares the task-related learning materials, either in the form of paper or multimedia, for students and delivers them to the students via online social networking. The students are required to study task-related knowledge autonomously before the class. Under traditional teaching model, the teacher would apply lecture-based approach to deliver the knowledge which may ignore the personal needs of the students and the difference in students' learning ability. However, in flipped class, students could arrange their learning schedule according to their own language proficiency and receptivity, through which the language learners could realize personalized learning.

\subsection{The activities while class}

In the offline course which happens in the classroom, the learners would figure out "what to write" through kinds of activities designed by the teachers. The class activities include:

\begin{tabular}{|c|c|c|}
\hline Activities & Flows & Goals \\
\hline mind map & $\begin{array}{l}\text { students work in pairs and } \\
\text { use key words to draw a } \\
\text { mind map about the writing }\end{array}$ & $\begin{array}{l}\text { review and practice the } \\
\text { useful vocabulary } \\
\text { accumulated before class }\end{array}$ \\
\hline presentation & $\begin{array}{l}\text { the representative of } \\
\text { students states his thesis } \\
\text { statement on the writing } \\
\text { task and other students give } \\
\text { feedback on his opinion }\end{array}$ & $\begin{array}{l}\text { work on the thesis } \\
\text { statement /main topic of } \\
\text { the writing task }\end{array}$ \\
\hline brainstorm & $\begin{array}{l}\text { students work in groups } \\
\text { and brainstorm outlines of } \\
\text { the writing task }\end{array}$ & $\begin{array}{l}\text { draft the outline of the } \\
\text { writing task }\end{array}$ \\
\hline debate & $\begin{array}{l}\text { students work in pairs/ } \\
\text { groups to represent two } \\
\text { sides of an argument and } \\
\text { debate with each other } \\
\text { (often used in the argument } \\
\text { writing) }\end{array}$ & $\begin{array}{lll}\text { collect } & \text { reasons } & \text { and } \\
\text { examples } & \text { to support the } \\
\text { topic } & & \end{array}$ \\
\hline contest & $\begin{array}{l}\text { students work in groups to } \\
\text { compete with each other } \\
\text { about the synonyms of the } \\
\text { key words of the writing } \\
\text { task }\end{array}$ & $\begin{array}{l}\text { enrich vocabulary and } \\
\text { avoid repetition in the } \\
\text { after-class writing }\end{array}$ \\
\hline
\end{tabular}

Those are some examples of the activities commonly applied in the flipped college English writing class, but may not be limited to those. Different activities many be adopted for different kinds of writing task. The focus of offline flipped college English writing class is classroom activities. Kinds of activities would strengthen the interaction between the teacher and the students as well as among students themselves. As students have already acquired related knowledge before class, they may find easier to communicate and discuss the task with the teacher and peers in English, thus the English context is possible in the classroom, which is extremely necessary for EFL learners who do not live in an actual language environment. The classroom activities would prepare students well for the writing task, both in content and in language. 


\subsection{The output of the task and evaluation after class}

After the practice in the classroom activities, students would clearly figure out "what to write", and the content of the writing would no longer be a problem to them. For a flipped college English writing class, the specific writing task would be finished on the online writing platform "Pigai". The scale of college English class makes it impossible for teachers to examine and provide feedback to every student in a short time and the lack of assessment would hinder students' enthusiasm of participating in writing. With the aid of online writing platform, students' writing would be evaluated immediately and students could revise the vocabulary and grammar related errors according to the feedback. The teacher could focus on the evaluation of coherence and cohesion on the whole, which would ease the teacher's burden on assessment. Beside the application of the online writing platform, sometimes, group work would be adopted in the output stage. Students would be required to exchange writing with group members and assess each other's work. The students would realize the problem in their writing through identifying other's problems.

\section{Conclusions}

The flipped class model can help deal with the shortage of college English class and the personalized characteristics of different students. Under the flipped class model, the students would be motivated to learn autonomously. The activities have replaced the lectures in the classroom thus the interaction between the teacher and the students has been stimulated. The communication and discussion between the teacher and the students as well as among students can create an English context for students to practice output skills which would benefit them a lot in their future study and work. For a long time, one of the obstacles in popularizing the flipped class model in college English teaching is the difficulties in producing online teaching resources. For many college English teachers, they do not possess professional skills in making video, micro-lecture or massive open online courses (MOOC). Nevertheless, for a college writing class, the input before class is rather diverse. There are abundant online teaching resources available. The English publications, like newspapers and magazines, and the English videos, like TV programs, movies and TED talks all can be adopted for inputting knowledge before class. Also, the output of the writing task would be accomplished with the assistance of the third party platform. The flipped classroom brings a new model to the college English writing class, which can make up for the shortage of traditional teaching model.

\section{References}

[1] Department of Higher Education, The College English Curriculum Requirements, Foreign Language Teaching and Research Press, Beijing, 2007

[2] E. Mazur, Can We Teach Computer to Teach, Computer in Physics, 5(1), pp. 31-38, 1991

[3] Jonathon Bergmann \& Aaron Sams, flipping your classroom: Reach every student in every class every day, International Society for Technology in Education, Washington DC, 2012

[4] Li Jingnan \& Wu Zhongjie, Practice and Reflection on Flipped College English Class, Foreign Language in China, Vol. 68, PP. 4-9, 2015

[5] Wang Chunxia, Application of Flipping Classroom to English Writing Classes in College, Journal of Changchun Normal University (Humanities and Social Science), Vol.33, PP. 173-175, 2014

[6] Wen Qiufang. The Application of Output-driven Hypothesis in College English Teaching: Reflection and suggestion. Foreign Language World, Vol.159, PP.14-22, 2013 